
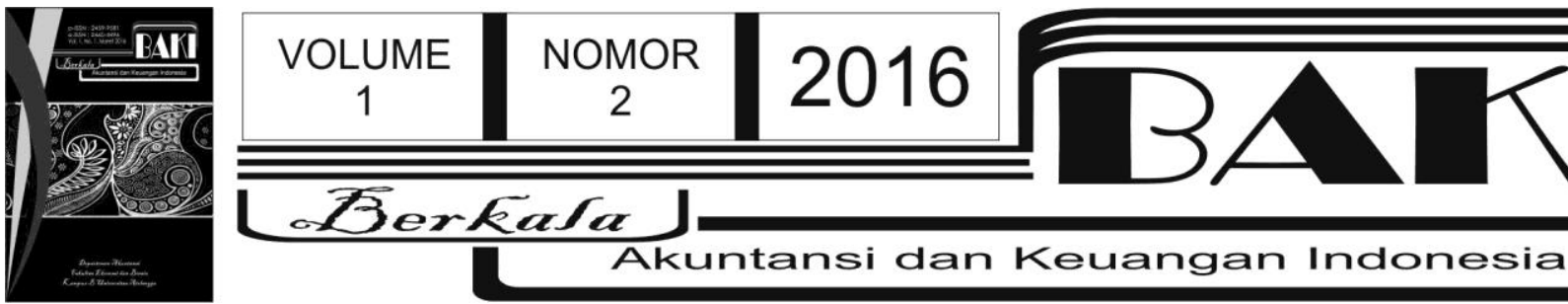

\title{
Berkata
}

Akuntansi dan Keuangan Indonesia

\section{Menakar Rasionalitas dalam Proses Pengukuran Kinerja dan Pengalokasian Sumberdaya Organisasi Sektor Publik}

\author{
I Putu Julianto*, Made Aristia Prayudi \\ *Universitas Pendidikan Ganesha \\ *putujulianto@undiksha.ac.id
}

\section{INFO ARTIKEL}

\section{Histori Artikel:}

Tanggal Masuk 14 Mei 2016

Tanggal Diterima 15 Agustus 2016

Tersedia Online 30 September 2016

Kata Kunci:

Balanced Scorecard(BSC); pengukuran kinerja; alokasi sumberdaya; aspek kognitif; kekuatan politik

\begin{abstract}
ABSTRAK
Penelitian ini bertujuan untuk menginvestigasi peran aspek rasional (kognitif) dan aspek non-rasional (kekuatan politik) dalam pengambilan keputusan organisasi berbasis Balanced Scorecard (BSC) terkait pengukuran kinerja dan alokasi sumber daya pada ranah sektor publik. Studi eksperimental kemudian dilakukan dengan melibatkan 70 mahasiswa Akuntansi jenjang strata-1 pada sebuah universitas publik terkemuka di Provinsi Bali. Partisipan diminta berperan sebagai seorang auditor pemerintah dengan tugas untuk mengevaluasi kinerja dua dinas pada suatu pemerintah daerah fiktif di Indonesia. Partisipan selanjutnya membuat rekomendasi terkait besaran bonus tambahan yang harus dialokasikan kepada kedua dinas yang telah dievaluasi kinerjanya. Hasil penelitian menunjukkan bahwa aspek kognitif memiliki pengaruh signifikan terhadap keputusan evaluasi kinerja, namun tidak berpengaruh signifikan terhadap keputusan alokasi sumber daya. Sementara itu, kekuatan politik terindikasi memiliki pengaruh yang signifikan terhadap keputusan alokasi sumber daya, namun tidak berpengaruh signifikan terhadap keputusan evaluasi kinerja. Dengan demikian, dapat disimpulkan bahwa proses pengukuran kinerja pada organisasi sektor publik lebih rasional dibandingkan dengan keputusan alokasi sumber daya.
\end{abstract}

\section{Pendahuluan}

Dalam beberapa tahun terakhir, kualitas sistem pengukuran kinerja organisasi sektor publik telah menunjukkan perbaikan yang signifikan melalui penerapan Balanced Scorecard (BSC) sebagai sebuah instrumen pengukuran kinerja modern yang secara sistematis mampu mengintegrasikan perspektif kinerja keuangan dan non-keuangan (Abdallah and Alnamri 2015, Adams, Muir, and Hoque 2013, Northcott and Taulapapa 2012, Sharma and Gadenne 2011). Meskipun demikian, masih saja dapat diamati adanya permasalahan praktikal dalam 
pengimplementasian instrumen pengukuran kinerja tersebut (Goh 2012). Termasuk dalam hal ini adalah permasalahan yang dapat disebabkan oleh keterbatasan (bias) kognitif evaluator berupa pengabaian relatif atas komponen ukuran-ukuran kinerja unik (unique measures) dibanding ukuran-ukuran kinerja umum (common measures) ${ }^{1,2}$ Pengabaian semacam ini tentunya dapat mengurangi kebermanfaatan potensial yang ditaw arkan oleh BSC karena pada hakikatnya keunggulan instrumen justru terletak pada ukuran-ukuran unik pada masing-masing perspektifnya (Lipe and Salterio 2000, Dilla and Steinbart 2005, Kaplan and Wisner 2009).

Salah satu motivasi penelitian ini adalah keinginan untuk dapat memitigasi bias ukuran umum penggunaan BSC pada ranah sektor publik melalui teknik pemberian pengetahuan (knowedge) terkait teori dan pengembangan BSC sebagai pilihan di antara alternatif metode lainnya ${ }^{3}$. Teknik ini dipilih dengan memperhatikan penelitian aw al Lipe and Salterio (2000) yang berhasil menangkap fenomena pengabaian ukuran unik dalam pengambilan keputusan pada subjek penelitian dengan tingkat pengetahuan dan pengalaman penggunaan BSC yang rendah. Dilla and Steinbart (2005) selanjutnya melakukan studi eksperimental yang mengkonfirmasi ketepatan penggunaan teknik pemberian pengetahuan dalam meminimalisasi bias ukuran umum sebagaiaman dimaksud. Namun, eksperimen tersebut dilakukan dalam konteks organisasi bisnis serta hanya menggunakan kelompok treatment tanpa kontrol. Sementara itu, penelitian Baw ono, Halim, and Lord (2012) menemukan bahw a, dibandingkan dengan partisipan pada kelompok kontrol, subjek penelitian yang mendapat treatment pemberian pengetahuan memang lebih mungkin mempertimbangkan baik ukuran-ukuran unik maupun ukuran-ukuran umum sebagai dasar pengambilan keputusan pada organisasi sektor publik. Sayangnya, penelitian tersebut tidak secara spesifik mengaplikasikan BSC sebagai instrumen pengukuran kinerja dalam skenario eksperimennya.

Penelitian ini juga memiliki tujuan untuk menginvestigasi peran aspek politik sebagai suatu faktor non-rasional dalam proses evaluasi kinerja dan alokasi sumberdaya pada organisasi sektor publik. Karakteristik alamiah yang sarat nuansa politis (Surtees et al., 2014), adanya koalisi-koalisi kepentingan (Boddew yn and Brewer 1994) dan tujuan non-profit yang diemban (Reck 2000) membuat lingkungan pengambilan keputusan pada organisasi sektor publik memang sangat rentan terhadap pengaruh rasionalisasi faktor-faktor non-ekonomi. Sebagai contoh, meskipun dalam praktiknya secara umum angka rasio realisasi anggaran tahun sebelumnya merupakan dasar pertimbangan yang logis atas pengalokasian sumberdaya untuk tahun berikutnya, pada organisasi dengan lingkungan yang relatif kurang kompetitif layaknya pada organisasi sektor publik, mekanisme yang berjalan tidaklah sesederhana itu. Penggunaan

\footnotetext{
${ }^{1}$ Ukuran kineja umum adalah ukuran-ukuran yang berlaku universal bagi seluruh unit terevaluasi, sementara ukuran kinerja unik lebih bersifat spesifik sesuai karakteristik tertentu unit-unit organisasi terkait.

${ }^{2}$ Lipe and Salterio (2000) pertama kali menyebut bias kognitif seperti ini sebagai bias ukuran umum (common measure bias)

${ }^{3}$ Lihat Kaplan and Wisner (2009) untuk review terkait metode-metode pemitigasi yang dimaksud.
} 
kekuatan-kekuatan politik berpotensi semakin meningkat dalam lingkungan organisasi seperti ini (Baw ono, Halim, and Lord 2012). Strategi pengambilan keputusan yang rasional, optimal dan terkomputasi dapat menjadi tak bermakna ketika kompromi-kompromi politik yang kemudian justru lebih mendominasi (Pfeffer and Salancik 1974). Peran aspek politik dalam pembuatan keputusan ekonomi organisasi sektor publik sebagaimana dimaksud, dengan demikian, menjadi topik yang menarik untuk diteliti lebih jauh.

Sejauh pengamatan, sedikit penelitian yang kemudian berhasil mengkonfirmasi secara empiris pengaruh faktor politik terhadap keputusan alokasi sumberdaya pada lingkup organisasi sektor publik. Penelitian yang dilakukan Winarna and Murni (2007), misalnya, hanya menemukan keterdukungan atas dua dari enam dimensi latar belakang politik, yaitu 'asal partai politik' dan 'asal komisi', sebagai faktor yang diduga berpengaruh terhadap peran pengaw asan keuangan daerah yang diemban oleh pihak legislatif. Di lain pihak, hasil positif dan signifikan diperoleh Pfeffer and Salancik (1974) dalam pengujian pengaruh aspek politik berupa daya tawar subjek evaluasi pada pembuatan keputusan terkait proses alokasi sumberdaya pada sebuah universitas publik. Sementara itu, Reck (2000) yang menggunakan ideologi politik sebagai variabel determinan justru menghasilkan derajat pemengaruhan yang bersifat marjinal. Inkonsistensi hasil penelitian-penelitian tersebut patut diduga disebabkan oleh perbedaan pemilihan proksi atas konstruk aspek politik yang memang kompleks dan terkait dengan berbagai dimensi.

Penelitian ini secara umum memperluas penelitian Baw ono, Halim, and Lord (2012) dan Sulistyanti (2012) yang menguji pengaruh pengetahuan (knowledge) tentang sistem pengukuran kinerja terhadap pertimbangan atas ukuran-ukuran umum dan unik BSC dalam pembuatan keputusan alokasi anggaran organisasi sektor publik. Perluasan dilakukan dengan menambahkan variabel aspek politik yang terproksi sebagai dimensi kekuatan (daya kompromi) relatif subjek evaluasi terhadap tercapainya tujuan pihak tertentu dalam organisasi dan/atau organisasi secara keseluruhan (Pfeffer and Salancik 1974). Hal ini sekaligus menjadi suatu perbaikan (refinement) atas penelitian yang dilakukan Winarna and Murni (2007) dan Reck (2000). Dengan demikian, hasil penelitian ini diharapkan mampu berkontribusi terhadap pengembangan ilmu dan praktik Akuntansi Sektor Publik dengan memberikan penjelasan dan gambaran yang lebih holistik dan komprehensif atas lingkungan pengambilan keputusan ekonomi pada ranah organisasi sektor publik.

Bagian selanjutnya dalam tulisan ini menyajikan sesi kerangka teoretis dan pengembangan hipotesis, diikuti dengan pemaparan metode penelitian yang digunakan, penyampaian hasil dan pembahasan, serta ditutup dengan bagian kesimpulan, implikasi dan keterbatasan penelitian. 


\section{Tinjauan Pustaka}

\subsection{Penggunaan BSC pada Organisasi Sektor Publik}

Meskipun pada awalnya ditujukan sebagai instrumen pengukuran kinerja kontemporer pada sektor swasta, BSC sesungguhnya juga dapat menjadi solusi revolusioner bagi permasalahan manajerial dan akuntabilitas yang dihadapi sektor publik (Adams, Muir, and Hoque 2013), bahkan dengan potensi manfaat yang lebih besar ketika diterapkan pada jenis organisasi ini (Kaplan 1999). Beberapa literatur telah mendokumentasikan hasil-hasil positif yang dapat muncul dari penerapan BSC pada ranah sektor publik. Kaplan (2001), misalnya, mengungkap bahw a BSC akan memungkinkan (1) penjembatanan kesenjangan antara tujuan yang tidak jelas dan pernyataan-pernyataan strategi serta aktivitas-aktivitas operasional harian organisasi; (2) pengembangan suatu proses dalam rangka pencapaian fokus strategis dan penghindaran patologi usaha-usaha penyediaan semua jenis layanan bagi semua orang; dan (3) penyelarasan inisiatif-inisiatif, departemen-departemen dan individu-individu untuk bekerja dengan cara-cara yang saling memperkuat satu sama lain sehingga peningkatan kinerja yang dramatis dapat tercapai. Northcott and Taulapapa (2012) menambahkan, BSC yang diterapkan dalam pengelolaan organisasi pemerintah daerah mampu (1) memperjelas tujuan-tujuan stratejik organisasi; (2) mengintegrasikan tujuan lintas unit organisasi; (3) memfokuskan ukuran kinerja menjadi lebih bermakna dan dapat lebih dikelola; serta (4) menyediakan link antara misi dan strategi organisasi.

\subsection{Bias Kognitif Penggunaan BSC}

Sebagaimana dinyatakan oleh Sulistyanti (2012), para pengguna Balanced Scorecard (BSC) memang memiliki kecenderungan untuk lebih mempertimbangkan ukuran-ukuran kinerja umum (common measures) dibandingkan ukuran-ukuran kinerja unik (unique measures) dalam mengevaluasi kinerja bawahannya. Hal ini tentu akan mengurangi kebermanfaatan penggunaan BSC, karena sebenarnya keunggulan sistem ini terletak justru pada ukuran-ukuran unik pada masing-masing perspektifnya (Lipe and Salterio 2000). Mempertimbangkan hal ini, banyak peneliti yang kemudian mencoba mencari solusi untuk meminimalisasi, bahkan jika mungkin mengeliminasi, bias kognitif terkait pembuatan keputusan berdasar BSC tersebut. Kaplan and Wisner (2009) menginventarisasi beberapa metode debiasing yang telah digunakan, seperti melalui invoking process accountability dan penyediaan assurance report dari pihak ketiga yang independen, implementasi pendekatan disagregated/mechanically agregated atau pemberian pengetahuan terkait penggunaan BSC itu sendiri. Teknik-teknik 
sebagaimana dimaksud telah terbukti berhasil untuk, paling tidak, meminimalisasi kecenderungan diberikannya perhatian hanya pada ukuran-ukuran umum dibandingkan ukuranukuran unik dalam penggunaan BSC.

\subsection{Aspek Kognitif, Penilaian Kinerja dan Pengalokasian Sumberdaya}

Logika penerapan pemberian pengetahuan dalam rangka memitigasi common measure bias pada penggunaan BSC beraw al dari temuan Slovic and Mac Phillamy (1974) serta Lipe and Salterio (2000) berupa kecenderungan penggunaan ukuran-ukuran umum dibandingkan ukuran-ukuran unik BSC sebagai pertimbangan dalam pembuatan keputusan organisasional oleh subjek yang tidak memiliki pengetahuan khusus terkait ukuran-ukuran tersebut. Ketiadaan pengetahuan yang memadai mengenai derajat kepentingan masing-masing tipe ukuran ditengarai dapat menstimulus alur berpikir subjek untuk secara heuristik berkonsentrasi hanya pada ukuran-ukuran yang dipersepsikan lebih bersifat umum dalam rangka menyederhanakan tugas penilaian yang dibebankan. Penggunaan informasi-informasi dan kriteria-kriteria umum sebagai acuan dalam penilaian memang diakui dapat mempermudah proses, terutama dalam tahapan pembandingan kualitas kinerja antar unit-unit organisasi yang dievaluasi (Slovic and MacPhillamy 1974).

Studi eksperimen Dilla and Steinbart (2005) kemudian menemukan bukti bahw a partisipan yang berpengetahuan dan berpengalaman dalam perancangan BSC lebih mungkin menggunakan kedua jenis ukuran tersebut ketika melakukan proses penilaian kinerja dan pemberian bonus bagi divisi terevaluasi. Hasil serupa, dalam konteks organisasi sektor publik di Indonesia, juga teramati dari penellitian Baw ono, Halim, and Lord (2012) pada mahasiswa S1 yang berperan sebagai anggota Dew an Perwakilan Rakyat Daerah (DPRD). Pemberian pengetahuan kepada partisipan dalam penelitian tersebut terbukti berpengaruh signifikan terhadap keputusan penilaian kinerja dan pengalokasian sumberdaya melalui pertimbangan secara proporsional atas aspek kinerja umum dan aspek kinerja unik unit organisasi terevaluasi. Berdasarkan pemaparan sebelumnya, dapat dirumuskan hipotesis pertama dalam penelitian ini yang memprediksi pengaruh aspek kognitif (faktor rasional) sebagai berikut:

$H_{1 a}$ : Partisipan yang memiliki pengetahuan terkait penggunaan BSC akan mempertimbangkan baik ukuran kinerja umum maupun ukuran kinerja unik dalam pengambilan keputusan penilaian kinerja.

$H_{1 b} \quad$ : Partisipan yang memiliki pengetahuan terkait penggunaan BSC akan mempertimbangkan baik ukuran kinerja umum maupun ukuran kinerja unik dalam pengambilan keputusan pengalokasian sumberdaya. 


\subsection{Aspek Politik, Penilaian Kinerja dan Pengalokasian Sumberdaya}

Model Koalisi Organisasi memandang bahw a elemen-elemen dalam organisasi memiliki nilai-nilai dan tujuan-tujuan yang beragam (Cyert and March 1963, Pfeffer and Salancik 1974). Dengan demikian, ketika muncul ketidaksepahaman atas tujuan atau atas hubungan antara tindakan yang dilakukan dan hasil yang diharapkan, strategi yang kemudian digunakan adalah kompromi-kompromi yang bersifat politis. Kekuatan relatif suatu unit tertentu berupa klaim atas peran penting unit tersebut-dibandingkan unit lainnya-terhadap keberhasilan organisasi secara keseluruhan, selanjutnya akan menentukan keberhasilan strategi ini. Kondisi sebagaimana dimaksud tampak relevan pada jenis organisasi pemerintahan yang memang seringkali tidak memiliki kesamaan pandangan terhadap suatu isu tertentu akibat adanya koalisi-koalisi kepentingan yang berfokus pada tujuan-tujuan yang beragam bahkan seringkali saling bertentangan (Boddew yn and Brew er 1994).

Sebagai sebuah keputusan yang berimplikasi pada kepentingan publik, pengalokasian sumberdaya tak dapat dipungkiri merupakan suatu hal yang lebih bersifat politis daripada teknokratis murni (Norton and Elson 2002), berlogika ekonomi (Reck 2000), atau berlandaskan rasionalitas yang terkomputasi (Pfeffer and Salancik 1974). Penggunaan power dan manipulasi pengaruh memang kemudian dapat muncul ketika suatu organisasi dihadapkan pada permasalahan-permasalahan terkait pemerolehan sumberdaya seperti ini (Latif, Abideen, and Nazar 2011). Di sisi lain, penelitian Kacmar and Ferris (1993) juga telah menemukan bahwa perihal pemberian reward sebagai konsekuensi dari aktivitas penilaian kinerja dapat sangat dipengaruhi oleh agenda pribadi sang evaluator, bukannya kualitas kinerja aktual karyawan. Ironisnya, kondisi seperti ini dapat terjadi bahkan pada organisasi yang telah memiliki kebijakan penilaian kinerja yang jelas dan terkomunikasi dengan baik. Berdasarkan pemaparan tersebut, dirumuskan hipotesis kedua penelitian ini yang memprediksi pengaruh aspek politik (faktor nonrasional) sebagai berikut:

$H_{2 a} \quad$ : Faktor Kekuatan Politik akan berpengaruh terhadap keputusan partisipan terkait proses penilaian kinerja.

$\mathrm{H}_{2 b} \quad$ : Faktor Kekuatan Politik akan berpengaruh terhadap keputusan partisipan terkait proses pengalokasian sumberdaya.

\section{Metodologi Penelitian}

\subsection{Rancangan Penelitian}

Penelitian ini menggunakan pendekatan studi eksperimen, yaitu suatu riset yang didesain untuk menginvestigasi fenomena melalui perekayasaan (manipulasi) keadaan atau kondisi 
dengan prosedur tertentu untuk kemudian mengamati serta melakukan interpretasi atas hasil perekayasaan tersebut (Nahartyo 2012). Desain eksperimen dalam penelitian ini diadaptasi dari eksperimen yang dilakukan oleh Lipe and Salterio (2000) sebagaimana juga telah banyak digunakan dan dimodifikasi pada penelitian-penelitian terkait common measure bias penggunaan BSC (misalnya Dilla and Steinbart (2005), Baw ono, Halim, and Lord (2012), Sulistyanti (2012)). Modifikasi minor kemudian dilakukan melalui penyesuaian jenis tugas eksperimen dengan karakteristik pengukuran kinerja pada organisasi sektor publik di Indonesia.

Objek evaluasi adalah kinerja Dinas Kesehatan dan Dinas Pendidikan pada suatu kabupaten $\mathrm{X}$ yang bersifat fiktif untuk selanjutnya dijadikan sebagai dasar pertimbangan dalam pengalokasian sumber daya dengan proporsi tertentu kepada kedua dinas tersebut. Pada pengerjaan tugas eksperimen, partisipan mendapatkan tiga jenis treatment (perlakuan), yaitu (1) pemberian pola skor kinerja yang berbeda pada kedua dinas untuk masing-masing jenis ukuran kinerja (ukuran kinerja umum dan ukuran kinerja unik); (2) pemberian pengetahuan mengenai teknik penilaian kinerja berdasarkan BSC melalui sebuah kuliah singkat (short course) sebagai manipulasi atas variabel aspek kognitif; dan (3) pemberian informasi tambahan mengenai keunggulan (power) relatif yang dimiliki salah satu unit subjek evaluasi yang dapat dipertimbangkan sebagai manipulasi atas aspek kekuatan politik.

Pengujian hipotesis penelitian dilakukan melalui dua tahapan, yaitu tahapan I terkait pengujian pengaruh aspek kognitif dan kekuatan politik terhadap keputusan penilaian kinerja; dan tahapan II terkait pengujian pengaruh aspek kognitif dan kekuatan politik terhadap keputusan pengalokasian sumberdaya. Tahapan I menggunakan desain berpola faktorial $2 \times 2$ between-subject (faktor independen pertama dan kedua) dalam konjungsi dengan 2-tingkat faktor within-subject ${ }^{4}$ (faktor independen ketiga). Faktor independen between-subject pertama dan kedua berupa total empat pola kinerja tertentu untuk kedua subjek evaluasi-skor kinerja masing-masing dinas yang dievaluasi akan saling mengungguli baik pada ukuran kinerja umum maupun ukuran kinerja uniknya. Faktor independen ketiga adalah kedua subjek evaluasi kinerja, yaitu Dinas Pendidikan dan Dinas Kesehatan yang berperan sebagai faktor untuk desain within-subject. Desain ini digunakan baik pada partisipan kelompok 'non-kognitif' dan 'kognitif' maupun partisipan kelompok 'non-politik' dan 'politik' untuk kemudian diperbandingkan besarnya perbedaan mean skor kinerja yang dihasilkan oleh partisipan pada kedua pasangan kelompok tersebut. Pada tahapan II (Tabel 1), digunakan desain faktorial $2 \times 2$ between subject dengan variabel aspek kognitif 2-tingkat ('non-kognitif' dan 'kognitif') dan variabel kekuatan politik 2-tingkat ('non-politik' dan 'politik').

\footnotetext{
${ }^{4}$ Desain within-subject membandingkan pengaruh perlakuan yang berbeda pada subjek yang sama, sementara desain between-subject membandingkan penganuh perlakuan yang berbeda pada subjek yang berbeda (Nahartyo 2012).
} 


\section{Gambar 1}

Desain Eksperimen 2 x 2 Between-Subject Keputusan Pengalokasian Bonus

\begin{tabular}{|c|c|c|}
\hline & Non-Kognitif & Kognitif \\
\hline Non-Politik & & \\
\hline Politik & & \\
\hline
\end{tabular}

\subsection{Definisi Operasional dan Pengukuran Variabel}

Variabel terikat dalam penelitian ini adalah Skor Evaluasi Kinerja (skor_kinerja) dan Besaran Alokasi Dana Stimulan (alokasi_bonus). 'Skor_Kinerja' diukur dengan tipe skala interval pada rentang 101 poin, dengan poin '0' berlabel 'Dipindahtugaskan' (Reassign) dan poin '100' berlabel 'Luar Biasa' (Excellent) (Dilla and Steinbart 2005, Lipe and Salterio 2000, Sulistyanti 2012). Sementara 'Alokasi_Bonus' diukur dengan tipe skala rasio bersatuan IDR (Indonesian Rupiah) pada rentang besaran Rp 0,00 - Rp 100.000.000,00 (seratus juta rupiah) (Sulistyanti 2012). Sementara itu, terdapat tiga variabel bebas yang diharapkan akan berpengaruh terhadap salah satu atau kedua variabel terikat yang dimaksud, yaitu (1) Pola Kinerja, yaitu komposisi indikator kinerja (ukuran umum maupun ukuran unik) yang terklasifikasi ke dalam empat kelompok pola kinerja ('Ukuran Umum Mengunggulkan Dinas Pendidikan'; 'Ukuran Umum Mengunggulkan Dinas Kesehatan'; 'Ukuran Unik Mengunggulkan Dinas Pendidikan'; dan 'Ukuran Unik Mengunggulkan Dinas Kesehatan') (Lipe and Salterio 2000); (2) Aspek Kognitif, yaitu kepemilikan pemahaman atas penggunaan BSC sebagai instrument pengukuran kinerja terutama pemahaman atas keterkaitan masing-masing tipe ukuran (ukuran umum dan ukuran unik) dan kesetaraan prioritas kepentingan masing-masing tipe ukuran tersebut (Baw ono, Halim, and Lord 2012); serta (3) Kekuatan Politik, yaitu pengaruh relatif yang dimiliki oleh subyek evaluasi untuk mempengaruhi keputusan-keputusan evaluator sehingga bersedia mengalokasikan sumberdaya pada besaran yang paling mendekati jumlah yang diajukan oleh subyek evaluasi (Pfeffer and Salancik 1974).

\subsection{Subjek Penelitian}

Eksperimen dilakukan dengan melibatkan 70 partisipan (63\% berjenis kelamin perempuan) yang berasal dari mahasiswa Jurusan Akuntansi Program S1 Fakultas Ekonomi dan Bisnis Universitas Pendidikan Ganesha pada semester VI. Pertimbangan yang digunakan dalam pemilihan sampel adalah bahw a (1) partisipan telah menempuh mata kuliah Akuntansi Sektor Publik dan Sistem Pengendalian Manajemen; (2) karakteristik tugas eksperimen (experiment task) cukup relevan dengan pola pikir dan pola pengambilan keputusan mahasiswa Strata-1 pada semester akhir (Nahartyo 2012). Masing-masing partisipan kemudian berperan sebagai 
anggota tim evaluator dari inspektorat pemerintah kabupaten $\mathrm{X}$, salah satu kabupaten yang akan mengimplementasikan BSC dalam pengukuran kinerja bagi Satuan Kerja Perangkat Daerah (SKPD) di lingkungan kerjanya.

\subsection{Prosedur dan Skenario Eksperimen}

Pada tahap pertama, partisipan dibagi ke dalam dua kelompok, yaitu kelompok yang diberikan pelatihan singkat terkait common dan unique performance measure selama kurang lebih satu jam dan kelompok lain yang tidak mendapat pelatihan tersebut. Materi pelatihan yang diberikan berupa: (1) pendefinisian dan penjelasan terminologi 'kinerja', 'pengukuran kinerja' dan tujuan-tujuan pengukuran kinerja; (2) pendefinisian dan penjelasan tentang proses alokasi anggaran; (3) instruksi singkat mengenai teknik dalam membaca dan menginterpretasikan laporan kinerja dinas-dinas fiktif berbasis BSC yang mengandung beberapa informasi keuangan dan non-keuangan, ukuran umum dan unik di masing-masing informasi tersebut, serta pentingnya pengukuran-pengukuran yang bersifat unik untuk menilai kinerja organisasi; serta (4) partisipan diberikan jeda w aktu sekitar 10 menit untuk meresapi keseluruhan materi yang telah diberikan.

Selanjutnya, masing-masing partisipan pada kedua kelompok (A dan B), akan mendapat salah satu dari dua amplop yang berisikan dua kasus berbeda (satu amplop berisikan kasus dengan manipulasi kekuatan politik, satu amplop lainnya kasus tanpa manipulasi kekuatan politik). Kasus yang diberikan menggambarkan tingkat pencapaian kinerja dua dinas (kesehatan dan pendidikan) di Kabupaten $X$ yang relatif seimbang. Judgement pertama yang diinstruksikan kepada partisipan adalah pemberian skor tertentu (pada rentang '0' - '100') atas kinerja masing-masing dinas serta instruksi untuk mengungkapkan ukuran kinerja (umum atau unik) yang menjadi pertimbangan utama atas pemberian skor tersebut. Judgement kedua adalah keputusan pengalokasian dana operasional tambahan kepada masing-masing dinas. Dari total dana sebesar Rp 100.000.000,00 (seratus juta rupiah), partisipan diminta menentukan berapa besaran dana yang dialokasikan untuk Dinas Kesehatan dan berapa porsi untuk Dinas Pendidikan.

Pemberian manipulasi kekuatan politik disisipkan pada salah satu amplop yang diterima secara acak oleh sebagian partisipan. Untuk kasus berisi treatment ini, diberikan tambahan informasi bahwa salah satu indikator keberhasilan pembangunan dan pencapaian kesejahteraan masyarakat suatu daerah adalah angka Indeks Pembangunan Manusia, yang dilihat dari komponen usia hidup, pengetahuan dan standar hidup layak. Pencapaian IPM suatu kabupaten kemudian akan menentukan kualitas kinerja dan kebijakan politik yang dibuat oleh pemerintah daerah di mata masyarakat. Ditambahkan bahw a data historis telah menunjukkan bahwa secara statistik tingkat kesehatan dan daya beli masyarakat Kabupaten $\mathrm{X}$ sangat 
dipengaruhi oleh besarnya penghasilan masyarakat dengan latar belakang pendidikan minimal SMA/sederajat. Informasi ini diharapkan dapat memberikan stimulan bagi partisipan untuk mempertimbangkan tingkat kekuatan taw ar (bargaining power) Dinas Pendidikan yang relatif lebih tinggi dibandingkan Dinas Kesehatan sehingga dapat berpengaruh signifikan bagi partisipan untuk mengalokasikan dana operasional tambahan yang relatif lebih besar kepada Dinas Pendidikan.

Pembagian amplop dilakukan secara acak (random). Peneliti kemudian menjelaskan instruksi pelaksanaan eksperimen dan mengumumkan bahw a di akhir kegiatan akan diberikan paket hadiah bagi partisipan yang memberikan jawaban sesuai dengan kriteria peneliti dalam rangka menstimulasi pengerjaan yang sungguh-sungguh atas tugas eksperimen tersebut. Pengerjaan tugas eksperimen dibatasi selama 30 menit dengan hasil akhir yang diharapkan berupa pemberian judgement sebagai berikut: (1) pemberian skor evaluasi kinerja secara keseluruhan dalam skala '0' sampai '100', dengan '0' merepresentasikan perlunya kepala dinas 'dipindahtugaskan' dan '100' merepresentasikan kinerja kepala dinas yang 'luar biasa'; serta (2) keputusan besaran bonus yang akan dialokasikan kepada masing-masing kepala dinas dari jumlah bonus total sebesar Rp 100.000.000,00 (seratus juta rupiah).

Tahapan terakhir berupa pengisian kuesioner terkait informasi demografis dan beberapa pertanyaan penutup yang mengindikasikan tentang cek manipulasi, tingkat pemahaman subjek terhadap kasus yang disajikan, serta menangkap reaksi partisipan atas stimulus 'kekuatan politik' yang diberikan kepada partisipan. Pertanyaan-pertanyaan demografis yang diajukan berupa pertanyaan terkait jenis kelamin, umur, dan lama pengalaman kerja (jika ada). Beberapa orang yang jaw abannya sesuai dengan kriteria peneliti selanjutnya mendapat imbalan berupa paket hadiah sebagaimana dijanjikan di aw al.

\section{Analisis dan Pembahasan}

\subsection{Penilaian Kinerja}

Pengujian terhadap hipotesis $\mathrm{H} 1$ a dan $\mathrm{H} 2$ a terkait pengaruh aspek kognitif dan kekuatan politik dalam penilaian kinerja organisasi dilakukan menggunakan uji ANOVA $2 \times 2 \times 2$ dengan ukuran umum dan ukuran unik sebagai variabel-variabel between-subject dan dinas-dinas sebagai ukuran-berulang (repeated measure). Sebagai temuan aw al (panel A Tabel 2, Tabel 3, Tabel 4 dan Tabel 5), hubungan interaksi antara kinerja dinas dan ukuran umum terbukti signifikan untuk kelompok 'non-kognitif' ( $p$-value $=0,009)$, 'kognitif' $(p$-value $<0,001)$ dan kelompok 'politik' ( $p$-value $<0,001$ ), namun tidak signifikan untuk kelompok 'non-politik' ( $p$-value $=0,095)$. Sementara itu, signifikansi hubungan interaksi juga ditemukan antara kinerja dinas dan ukuran unik untuk kelompok 'non-kognitif' ( $p$-value $=0,024)$, 'kognitif' $(p$-value $=0,012)$, 
'non-politik' ( $p$-value $=0,010)$ serta 'politik' ( $p$-value $=0,023)$. Temuan ini dapat menjadi indikasi bahw a proses penilaian kinerja dinas yang dilakukan partisipan pada keempat kelompok secara signifikan dipengaruhi oleh kedua jenis ukuran tersebut, kecuali untuk kelompok 'non-politik'. Analisis lanjutan kemudian menemukan bahw a, secara umum, ukuran kinerja umum relatif lebih dipertimbangkan dibandingkan ukuran kinerja unik dalam hal penilaian kinerja ${ }^{5}$.

Hipotesis $\mathrm{H} 1 \mathrm{a}$ diuji dengan membandingkan besarnya perbedaan skor kinerja kedua dinas pada partisipan kelompok 'non-kognitif' dan partisipan kelompok 'kognitif' ketika masing-masing ukuran kinerja saling mengungguli. Hasil analisis kemudian disajikan pada panel B Tabel 2 dan panel B Tabel 3. Ditemukan bahw a perbedaan mean skor kinerja kedua dinas ketika ukuran umum mengunggulkan Dinas Pendidikan (Dinas Kesehatan) lebih tinggi pada kelompok 'kognitif' sebesar 4,86 $(8,00)$ point dibandingkan pada kelompok 'non-kognitif' sebesar 1,47 $(7,33)$ point. Demikian pula, perbedaan mean skor kinerja kedua dinas ketika ukuran unik mengunggulkan Dinas Pendidikan (Dinas Kesehatan) juga ditemukan lebih tinggi pada kelompok 'kognitif' sebesar 4,34 $(6,67)$ point dibandingkan pada kelompok 'non-kognitif' sebesar 0,76 $(3,75)$ point. Hal ini mengindikasikan bahwa pemberian pengetahuan (peningkatan aspek kognitif) mampu meningkatkan sensitivitas evualator atas perbedaan nilai pencapaian kinerja kedua dinas berdasarkan pertimbangan terhadap ukuran-ukuran kinerja umum dan ukuran unik BSC. Dengan demikian, hipotesis $\mathrm{H} 1 \mathrm{a}$ dalam penelitian ini dapat dinyatakan terdukung secara empiris.

\section{Tabel 2}

Hasil Penilaian Kinerja Dinas pada Partisipan Kelompok 'Non-Kognitif'

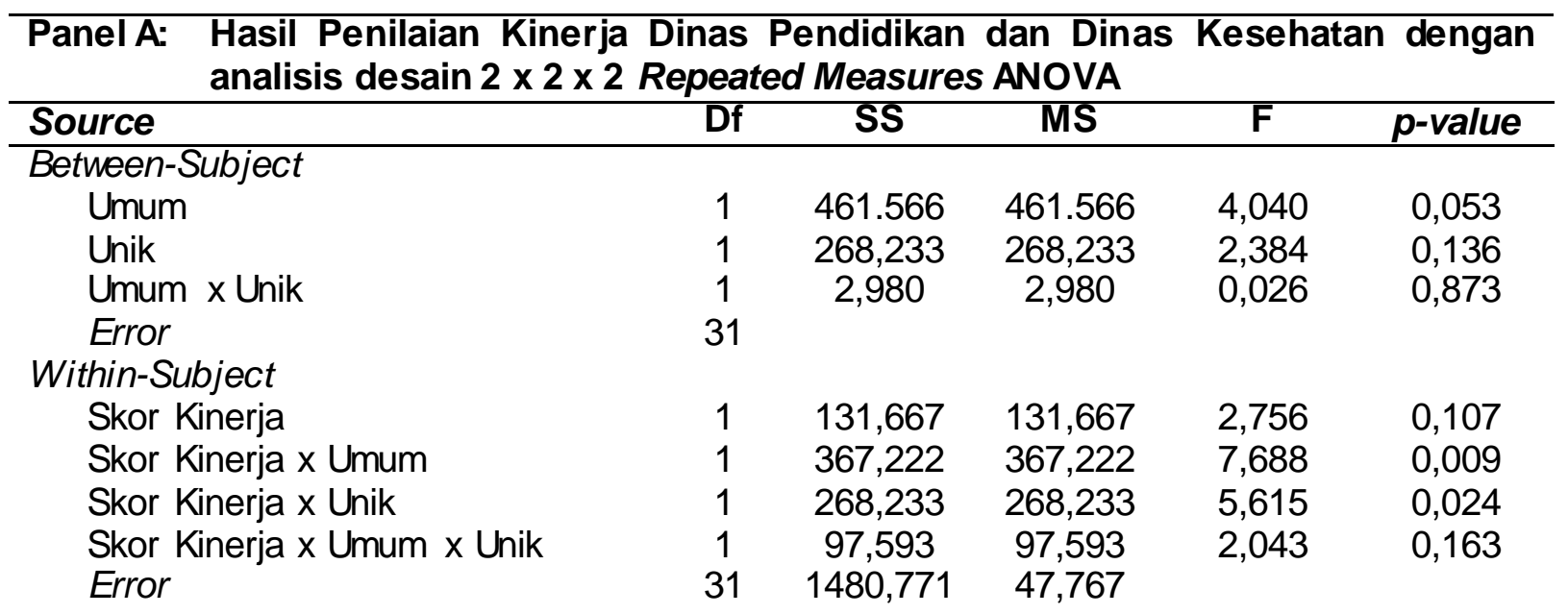

\footnotetext{
${ }^{5}$ Analis is lanjutan dilakukan melalui penghitungan nilai eta-squared dan pembandingan besaran perbedaan mean skor kinerja kedua dinas ketika masing-masing ukuran kinerja saling mengungguli, baik pada kelompok 'non-kognitif', 'kognitif', 'non-politik' dan 'politik'. Hasil analisis menunjukkan bahwa nilai eta-squared untuk kinerja dinas akibat pengaruh ukuran umum lebih tinggi dibandingkan nilai eta-squared akibat pengaruh ukuran unik serta perbedaan mean skor kinerja kedua dinas akibat pengaruh ukuran umum lebih besar dibandingkan akibat pengaruh ukuran kinerja unik, kecuali untuk kelompok 'non-politik'.
} 


\begin{tabular}{cccc}
\hline Panel B: & Penilaian Kinerja Dinas Pendidikan dan Dinas Kesehatan a \\
\hline & $\begin{array}{c}\text { Skor Dinas } \\
\text { Pendidikan }\end{array}$ & $\begin{array}{c}\text { Skor Dinas } \\
\text { Kesehatan }\end{array}$ & $\begin{array}{c}\text { Perbedaan Skor } \\
\text { Pendidikan - } \\
\text { Kesehatan }\end{array}$ \\
\hline Ukuran Umum & $\begin{array}{c}77,94^{\mathrm{b}} \\
(96,92)\end{array}$ & $\begin{array}{c}76,47 \\
(11,695)\end{array}$ & 1,47 \\
Mengunggulkan Dinas Pendidikan & 68,50 & 75,83 & $-7,33$ \\
Mengunggulkan Dinas Kesehatan & $(7,664)$ & $(7,524)$ & \\
Ukuran Unik & 76,94 & 76,18 & 0,76 \\
Mengunggulkan Dinas Pendidikan & $(9,826)$ & $(9,105)$ & $-3,75$ \\
Mengunggulkan Dinas Kesehatan & 76,05 & 79,80 & $(10,369)$ \\
\hline
\end{tabular}

Sumber : Output pengolahan data primer.

Keterangan : aPenilaian dilakukan menggunakan angka berskala 101, dengan 0 berlabel 'Dipindahtugaskan' dan 100 berlabel 'Luar Biasa'; 'Nilai pada panel adalah nilai means (standard deviations).

Tabel 3

Hasil Penilaian Kinerja Dinas pada Partisipan Kelompok 'Kognitif'

\begin{tabular}{|c|c|c|c|c|c|}
\hline \multicolumn{6}{|l|}{ Panel A: } \\
\hline Source & Df & SS & MS & $\mathbf{F}$ & p-value \\
\hline \multicolumn{6}{|l|}{ Between-Subject } \\
\hline Umum & 1 & 266,428 & 266,428 & 0,889 & 0,353 \\
\hline Unik & 1 & 30,740 & 30,740 & 0,103 & 0,751 \\
\hline Umum x Unik & 1 & 0,569 & 0,569 & 0,002 & 0,966 \\
\hline Error & 31 & & & & \\
\hline \multicolumn{6}{|l|}{ Within-Subject } \\
\hline Skor Kinerja & 1 & 9,816 & 9,816 & 0,325 & 0,573 \\
\hline Skor Kinerja x Umum & 1 & 526,594 & 526,594 & 17,431 & 0,000 \\
\hline Skor Kinerja x Unik & 1 & 216,375 & 216,375 & 7,163 & 0,012 \\
\hline $\begin{array}{l}\text { Skor Kinerja x Umum x Unik } \\
\text { Error }\end{array}$ & $\begin{array}{c}1 \\
31\end{array}$ & $\begin{array}{c}33,435 \\
936,491\end{array}$ & $\begin{array}{l}33,435 \\
30,209\end{array}$ & 1,107 & 0,301 \\
\hline
\end{tabular}

\begin{tabular}{lccc}
\hline Panel B: & Penilaian Kinerja Dinas Pendidikan dan Dinas Kesehatan a \\
\hline & $\begin{array}{c}\text { Skor Dinas } \\
\text { Pendidikan }\end{array}$ & $\begin{array}{c}\text { Skor Dinas } \\
\text { Kesehatan }\end{array}$ & $\begin{array}{c}\text { Perbedaan Skor } \\
\text { Pendidikan - } \\
\text { Kesehatan }\end{array}$ \\
\hline $\begin{array}{c}\text { Ukuran Umum } \\
\text { Mengunggulkan Dinas Pendidikan }\end{array}$ & $\begin{array}{c}77,86^{\mathrm{b}} \\
(15,541)\end{array}$ & $\begin{array}{c}73,00 \\
(13,164)\end{array}$ & 4,86 \\
Mengunggulkan Dinas Kesehatan & $\begin{array}{c}75,71 \\
83,71\end{array}$ & $-8,00$ \\
& $(10,163)$ & $(8,042)$ & \\
Ukuran Unik & 78,27 & 73,93 & 4,34 \\
Mengunggulkan Dinas Pendidikan & $(11,342)$ & $\begin{array}{c}(10,457) \\
76,11\end{array}$ & $-6,67$ \\
Mengunggulkan Dinas Kesehatan & 69,44 & $(13,466)$ & \\
\hline
\end{tabular}


Keterangan : aPenilaian dilakukan menggunakan angka berskala 101, dengan 0 berlabel 'Dipindahtugaskan' dan 100 berlabel 'Luar Biasa'; bNilai pada panel adalah nilai means (standard deviations).

Dengan teknik serupa, hipotesis H2a diuji melalui pembandingan besaran perbedaan skor kinerja kedua dinas pada partisipan kelompok 'non-politik' dan partisipan kelompok 'politik' ketika masing-masing ukuran kinerja saling mengungguli. Sebagaimana tersaji pada pada panel B Tabel 4 dan panel B Tabel 5, perbedaan mean skor kinerja kedua dinas ketika ukuran umum mengunggulkan Dinas Pendidikan (Dinas Kesehatan) lebih tinggi pada kelompok 'politik' sebesar 4,84 $(10,44)$ point dibandingkan pada kelompok 'non-politik' sebesar 2,00 $(4,82)$ point. Sementara itu, perbedaan mean skor kinerja kedua dinas ketika ukuran unik mengunggulkan Dinas Pendidikan (Dinas Kesehatan) justru ditemukan lebih tinggi pada kelompok 'non-politik' sebesar 4,25 (5,25) point dibandingkan pada kelompok 'politik' sebesar 0,63 $(5,00)$ point. Hal ini membuktikan bahw a kekuatan politik hanya mampu meningkatkan sensitivitas evaluator atas perbedaan nilai pencapaian kinerja kedua dinas berdasarkan pertimbangan terhadap ukuranukuran kinerja umum BSC, bukan atas ukuran-ukuran kinerja uniknya. Dengan demikian, hipotesis $\mathrm{H} 2 \mathrm{a}$ dalam penelitian ini dapat dinyatakan tidak terdukung secara empiris.

Tabel 4

Hasil Penilaian Kinerja Dinas pada Partisipan Kelompok 'Non-Politik'

\begin{tabular}{|c|c|c|c|c|c|}
\hline $\begin{aligned} \text { Panel A: } & \text { Hasil Penilaian Kir } \\
& \text { analisis desain } 2 \times\end{aligned}$ & $\begin{array}{l}\text { nas } \\
\text { peat }\end{array}$ & $\begin{array}{l}\text { endidikan } \\
\text { Measure }\end{array}$ & $\begin{array}{l}\text { dan Dinas } \\
\text { ANOVA }\end{array}$ & Keseh & dengar \\
\hline Source & Df & SS & MS & $\mathbf{F}$ & p-value \\
\hline Between-Subject & & & & & \\
\hline Umum & 1 & 8,601 & 8,601 & 0,041 & 0,840 \\
\hline Unik & 1 & 215,030 & 215,030 & 1,037 & 0,316 \\
\hline Umum x Unik & 1 & 5,030 & 5,030 & 0,024 & 0,877 \\
\hline Error & 32 & & & & \\
\hline Within-Subject & & & & & \\
\hline Skor Kinerja & 1 & 10,744 & 10,744 & 0,237 & 0,629 \\
\hline Skor Kinerja x Umum & 1 & 133,601 & 133,601 & 2,953 & 0,095 \\
\hline Skor Kinerja x Unik & 1 & 340,744 & 340,744 & 7,531 & 0,010 \\
\hline Skor Kinerja x Umum x Unik & 1 & 3,601 & 3,601 & 0,080 & 0,780 \\
\hline Error & 32 & 1447,917 & 45,247 & & \\
\hline
\end{tabular}

\begin{tabular}{cccc}
\hline Panel B: & Penilaian Kinerja Dinas Pendidikan dan Dinas Kesehatana & \\
\hline & $\begin{array}{c}\text { Skor Dinas } \\
\text { Pendidikan }\end{array}$ & $\begin{array}{c}\text { Skor Dinas } \\
\text { Kesehatan }\end{array}$ & $\begin{array}{c}\text { Perbedaan Skor } \\
\text { Pendidikan - } \\
\text { Kesehatan }\end{array}$ \\
\hline $\begin{array}{c}\text { Ukuran Umum } \\
\text { Mengunggulkan Dinas Pendidikan }\end{array}$ & $\begin{array}{c}78,00^{\mathrm{b}} \\
(12,074) \\
\text { Mengunggulkan Dinas Kesehatan }\end{array}$ & $\begin{array}{c}76,00 \\
(13,727) \\
80,63\end{array}$ & 2 \\
Ukuran Unik & $(7,521)$ & $(9,881)$ & $-4,82$ \\
$\quad$ Mengunggulkan Dinas Pendidikan & 77,69 & 73,44 & 4,25
\end{tabular}




$\begin{array}{ccc} & & \\ \text { Mengunggulkan Dinas Kesehatan } & (8,340) & (8,509) \\ & 76,50 & 81,75 \\ & (11,709) & (13,599)\end{array}$

Sumber : Output pengolahan data primer.

Keterangan : aPenilaian dilakukan menggunakan angka berskala 101, dengan 0 berlabel 'Dipindahtugaskan' dan 100 berlabel 'Luar Biasa'; 'Nilai pada panel adalah nilai means (standard deviations)

Tabel 5

Hasil Penilaian Kinerja Dinas pada Partisipan Kelompok 'Politik'

\begin{tabular}{|c|c|c|c|c|c|}
\hline $\begin{array}{ll}\text { Panel A: } & \text { Hasil Penilaian Kin } \\
& \text { analisis desain } 2 \times 2\end{array}$ & $\begin{array}{l}\text { inas } \\
\text { epea }\end{array}$ & $\begin{array}{l}\text { endidikan } \\
\text { Measure }\end{array}$ & $\begin{array}{l}\text { dan Dinas } \\
\text { ANOVA }\end{array}$ & Keseha & dengan \\
\hline Source & Df & SS & MS & $\mathbf{F}$ & $p$-value \\
\hline Between-Subject & & & & & \\
\hline Umum & 1 & 144,095 & 144,095 & 0,707 & 0,407 \\
\hline Unik & 1 & 583,792 & 583,792 & 2,863 & 0,101 \\
\hline Umum $x$ Unik & 1 & 10,779 & 10,779 & 0,053 & 0,820 \\
\hline Error & 30 & & & & \\
\hline Within-Subject & & & & & \\
\hline Skor Kinerja & 1 & 110,592 & 110,592 & 3,695 & 0,064 \\
\hline Skor Kinerja x Umum & 1 & 1044,474 & 1044,474 & 34,898 & 0,000 \\
\hline Skor Kinerja x Unik & 1 & 171,118 & 171,118 & 5,717 & 0,023 \\
\hline Skor Kinerja x Umum x Unik & 1 & 21,316 & 21,316 & 0,712 & 0,405 \\
\hline Error & 30 & 897,875 & & & \\
\hline
\end{tabular}

\begin{tabular}{cccc}
\hline Panel B: & Penilaian Kinerja Dinas Pendidikan dan Dinas Kesehatan a \\
\hline & $\begin{array}{c}\text { Skor Dinas } \\
\text { Pendidikan }\end{array}$ & $\begin{array}{c}\text { Skor Dinas } \\
\text { Kesehatan }\end{array}$ & $\begin{array}{c}\text { Perbedaan Skor } \\
\text { Pendidikan - } \\
\text { Kesehatan }\end{array}$ \\
\hline $\begin{array}{cccc}\text { Ukuran Umum } \\
\text { Mengunggulkan Dinas Pendidikan }\end{array}$ & $\begin{array}{c}77,78^{\mathrm{b}} \\
(14,477)\end{array}$ & $\begin{array}{c}(11,112) \\
77,94\end{array}$ & 4,84 \\
Mengunggulkan Dinas Kesehatan & 67,50 & $-10,44$ \\
& $(9,487)$ & $(7,261)$ & \\
Ukuran Unik & 77,44 & 76,81 & 0,63 \\
Mengunggulkan Dinas Pendidikan & $(12,426)$ & $(10,710)$ & $-73,94$ \\
Mengunggulkan Dinas Kesehatan & 68,94 & $(8,781)$ & $-5,00$ \\
\hline
\end{tabular}

Sumber : Output pengolahan data primer.

Keterangan : aPenilaian dilakukan menggunakan angka berskala 101, dengan 0 berlabel 'Dipindahtugaskan' dan 100 berlabel 'Luar Biasa'; 'Nilai pada panel adalah nilai means (standard deviations).

Hasil pengujian terhadap hipotesis penelitian ini konsisten dengan temuan penelitian Dilla and Steinbart (2005) dalam konteks sektor sw asta serta penelitian Baw ono, Halim, and Lord (2012) pada lingkungan organisasi sektor publik yang menggunakan instrumen pengukuran kinerja menyerupai BSC. Meskipun demikian, selayaknya penelitian-penelitian terdahulu terkait bias ukuran umum (common measures bias) sistem pengukuran kinerja, partisipan yang 
berpengetahuan pada penelitian ini tampak masih lebih mempertimbangkan ukuran umum dibandingkan ukuran unik sebagai acuan pembuatan keputusannya.

\subsection{Pengalokasian Bonus}

Hipotesis $\mathrm{H} 1 \mathrm{~b}$ dan $\mathrm{H} 2 \mathrm{~b}$ terkait pengaruh aspek kognitif dan kekuatan politik dalam pengalokasian sumberdaya diuji menggunakan uji ANOVA 2 × 2 pada Dinas Pendidikan saja karena besaran sumberdaya yang dialokasikan kepada kedua dinas bersifat tetap (fixed amount) ketika dijumlahkan. Dengan demikian, uji ANOVA yang digunakan hanya menggabungkan variabel aspek kognitif dan kekuatan politik sebagai faktor-faktor betweensubject-nya. Hasil pengujian, sebagaimana tampak pada Tabel 6, menunjukkan bahwa terdapat signifikansi main effect variabel kekuatan politik $(p$-value $<0,01)$ terhadap variabel dependen 'alokasi_bonus'; namun main effect variabel aspek kognitif ditemukan tidak signifikan ( $p$-value = 0,429). Hal ini mengindikasikan bahw a keputusan pengalokasian sumberdaya oleh partisipan pada penelitian ini dipengaruhi oleh adanya kekuatan politik yang dipersepsikan dimiliki oleh Dinas Pendidikan relatif terhadap Dinas Kesehatan. Hasil ini diperkuat dengan dialokasikannya proporsi bonus yang lebih besar untuk Dinas Pendidikan oleh partisipan pada kelompok yang memperoleh treatment kekuatan politik (mean $=$ Rp 56.764.705,88) dibandingkan pada kelompok kontrol $($ mean $=49.027 .777,78)$ dengan nilai signifikansi $p$-value $=0,003$ seperti tersaji pada Tabel 7. Dengan demikian, hipotesis $\mathrm{H} 2 \mathrm{~b}$ dalam penelitian ini dapat dinyatakan terdukung, namun hipotesis $\mathrm{H} 1 \mathrm{~b}$ tidak terdukung secara empiris.

\section{Tabel 6}

Hasil Pengalokasian Bonus Dinas Pendidikan dengan analisis desain 2 × 2 ANOVA

\begin{tabular}{lccccc}
\hline Source & Df & SS & MS & F & p-value \\
\hline Intercept & 1 & $1,951 \mathrm{E}+17$ & $1,951 \mathrm{E}+17$ & 1810,684 & 0,000 \\
Kognitif & 1 & $6,839 \mathrm{E}+13$ & $6,839 \mathrm{E}+13$ & 0,635 & 0,429 \\
Politik & 1 & $1,013 \mathrm{E}+15$ & $1,013 \mathrm{E}+15$ & 9,401 & 0,003 \\
Kognitif x Politik & 1 & $3,052 \mathrm{E}+12$ & $3,052 \mathrm{E}+12$ & 0,028 & 0,867 \\
Error & 66 & $7,113 \mathrm{E}+15$ & $1,078 \mathrm{E}+14$ & & \\
\hline
\end{tabular}

Sumber: Output pengolahan data primer.

\section{Tabel 7}

Statistika Deskriptif Pengalokasian Bonus

\begin{tabular}{|c|c|c|c|c|}
\hline $\begin{array}{c}\text { Variabel } \\
\text { Independen }\end{array}$ & $\begin{array}{c}\text { Mean }^{a} \text { Alokasi } \\
\text { Bonus } \\
\text { Dinas Pendidikan }\end{array}$ & Perbedaan $^{a}$ & p-value & $\mathbf{N}$ \\
\hline $\begin{array}{l}\text { Non-Kognitif } \\
\text { Kognitif }\end{array}$ & $\begin{array}{l}51.571 .428,57 \\
54.000 .000,00\end{array}$ & $2.428 .571,43$ & 0,429 & $\begin{array}{l}35 \\
35\end{array}$ \\
\hline $\begin{array}{l}\text { Non-Politik } \\
\text { Politik }\end{array}$ & $\begin{array}{l}49.027 .777,78 \\
56.764 .705,88\end{array}$ & 7.736.928,10 & 0,003 & $\begin{array}{l}36 \\
34\end{array}$ \\
\hline
\end{tabular}

Sumber : Output pengolahan data primer.

Keterangan : ${ }^{a}$ Nilai yang tercantum dalam satuan Rupiah. 
Hasil ini konsisten dengan temuan penelitian klasik Pfeffer and Salancik (1974) dalam konteks alokasi anggaran pada sebuah universitas publik. Kekuatan (power) relatif yang dimiliki oleh sebuah sub unit organisasi dapat menjadi faktor penentu besaran sumberdaya yang teralokasi pada masing-masing sub unit. Semakin tinggi derajat power yang dimiliki, semakin mungkin sub unit tersebut memperoleh sumber daya dengan alokasi yang lebih besar. Temuan ini juga sekaligus mengkonfirmasi argumentasi Reck (2000) terkait lingkungan pengambilan keputusan alokasi anggaran yang irasional, politis dan non-ekonomis pada organisasi sektor publik.

\section{Kesimpulan, Keterbatasan, dan Saran}

Penelitian ini menerapkan suatu desain eksperimen laboratorium dalam rangka menemukan bukti empiris pengaruh aspek kognitif dan kekuatan politik terhadap keputusan penilaian kinerja dan pengalokasian sumberdaya organisasi berbasis BSC dalam konteks sektor publik. Hasil penelitian secara umum memberikan dukungan terhadap hipotesis terkait potensi penggunaan ukuran kinerja umum dan ukuran unik BSC secara lebih memadai oleh partisipan yang memiliki pengetahuan dalam mendesain BSC, relatif terhadap partisipan yang tidak berpengetahuan atas hal tersebut, dalam hal penilaian kinerja organisasi. Penelitian ini juga berhasil menemukan bukti hubungan pemengaruhan antara faktor kekuatan politik dan keputusan pengalokasian sumberdaya. Meskipun demikian, dugaan keterkaitan antara faktor rasional (kognitif) dan keputusan alokasi sumberdaya serta keterkaitan antara faktor nonrasional (politik) dan keputusan penilaian kinerja tidak dapat terdukung oleh data empiris.

Temuan-temuan pada penelitian ini memiliki implikasi luas bagi proses penilaian kinerja dan alokasi sumberdaya pada organisasi sektor publik. Pertama, ketidakseimbangan fokus evaluator terhadap penggunaan kedua jenis ukuran kinerja dapat membatasi efektivitas BSC sebagai intrumen pengukuran kinerja organisasi. Sebagaimana diungkapkan Holmstrom and Milgrom (1991), dalam suatu hubungan kontrak antara prinsipal dan agen, bentuk-bentuk indikator kinerja yang digunakan sebagai dasar pengukuran kinerja dan penentuan kompensasi akan sangat berpengaruh terhadap keputusan-keputusan yang dibuat oleh agen. Kondisi ini dapat semakin 'parah' ketika fenomena seperti ini berlaku di organisasi sektor publik dengan karakteristik sistem pengukuran kinerja yang difungsikan lebih sebagai tujuan (ends) ketimbang alat (means) pencapaian tujuan (Henri 2004). Kedua, hubungan positif antara faktor kekuatan politik dan keputusan alokasi sumber daya memberikan implikasi teoretis berupa pemahaman terkait lemahnya kemampuan prediktif atas aspek-aspek perilaku keorganisasian sebagaimana diajukan oleh konsep-konsep dalam Teori Pilihan Organisasi. Pencapaian tujuan yang optimal secara rasional dari sudut pandang organisasi secara keseluruhan tampak tidak relevan dalam 
lingkungan organisasi yang minim kompetisi dengan mana kekuatan-kekuatan politik mampu melingkupi proses pengambilan keputusan-keputusan, layaknya pada organisasi sektor publik.

Beberapa keterbatasan penelitian kemudian dapat diidentifikasi sehingga interpretasi terhadap hasil-hasil yang ditemukan bisa dilakukan secara lebih bijaksana. Pertama, meskipun hubungan interaksi aspek kognitif dan ukuran umum serta unik sebagai antecedent keputusan penilaian kinerja ditemukan signifikan, partisipan masih tetap lebih berfokus pada ukuran kinerja umum dibandingkan ukuran kinerja unik, bahkan pada kelompok kognitif. Hasil ini terjadi karena materi treatment pelatihan penyusunan dan pengembangan BSC yang diterima kemungkinan tidak terinternalisasi dengan baik dan merata oleh semua partisipan pada kelompok tersebut akibat waktu pelaksanaan pelatihan yang relatif singkat. Kedua, perbedaan mean skor kinerja yang diberikan baik dalam konteks ukuran umum maupun ukuran unik pada Dinas Kesehatan tampak lebih besar dibandingkan pada Dinas Pendidikan; konsisten di keempat kelompok penelitian. Hal ini menunjukkan bahw a tingkat sensitivitas partisipan terhadap materi yang terkandung dalam tugas eksperimen terkait bidang kesehatan lebih tinggi dibandingkan yang terkait dengan bidang pendidikan.

Penelitian selanjutnya dapat menerapkan strategi pemberian pengetahuan yang lebih intensif dan komprehensif. Di samping itu, perlu dilakukan pengujian aw al terkait keseimbangan relevansi indikator-indikator kinerja yang digunakan sebagai komponen ukuran umum dan ukuran unik dalam tugas eksperimen, pada masinng-masing sub unit organisasi yang dievaluasi. Terakhir, dengan memperhatikan hasil pengujian hipotesis penelitian yang menunjukkan tidak signifikannya pengaruh aspek kognitif (kekuatan politik) dalam pengambilan keputusan pengalokasian sumberdaya (penilaian kinerja) ketika pengaruh kekuatan politik (aspek kognitif) terbukti signifikan, penelitian selanjutnya dapat melakukan pengujian atas kemungkinan dominansi pengaruh aspek kognitif atas kekuatan politik, atau sebaliknya, terhadap pertimbangan pengambilan keputusan penilaian kinerja dan/atau pengalokasian sumberdaya organisasi.

\section{Daftar Pustaka}

Abdallah, Wagdy M., dan Majbour Alnamri. 2015. "Non-Financial Performance Measures and The BSC of Multinational Companies with Multi-Cultural Environment: An Empirical Investigation." Cross Cultural Management no. 22 (4):594-607.

Adams, Carol A., Stephen Muir, dan Zahirul Hoque. 2013. "Measurement of Sustainability Performance in the Public Sector." Sustainability Accounting, Management and Policy Journal no. 5 (1):46-67.

Baw ono, Icuk Rangga, Abdul Halim, dan Beverley Lord. 2012. Public Sector Performance Measurement and Budget Allocation: An Indonesian Experiment. In $6^{\text {th }} \mathrm{NZ}$ Management Accounting Conference. Palmerston North. 
Boddew yn, Jean J., dan Thomas L. Brew er. 1994. "International-Business Political Behavior: New Theoretical Directions." The Academy of Management Review no. 19 (1):119-143.

Cyert, Richard M., dan James G. March. 1963. A Behavioral Theory of the Firm. Englew ood Cliffs, N.J.: Prentice-Hall.

Dilla, William N., dan Paul John Steinbart. 2005. "Relative Weighting of Common and Unique Balanced Scorecard Measures by Knowledgeable Decision Makers." Behavioral Research In Accounting no. 17:45-53.

Goh, Swee C. 2012. "Making Performance Measurement Systems More Effective in Public Sector Organizations." Measuring Business Excellence no. 16 (1):31-42.

Henri, Jean-François. 2004. "Performance Measurement and Organizational Effectiveness: Bridging the Gap." Managerial Finance no. 30 (6):93-123.

Holmstrom, Bengt, dan Paul Milgrom. 1991. "Multitask Principal-Agent Analyses: Incentive Contracts, Asset Ownership, and Job Design." Journal of Law, Economics, \& Organization no. 7:24-52.

Kacmar, K. Michele, dan Gerald R. Ferris. 1993. "Politics at Work: Sharpening the Focus of Political Behavior in Organizations." Business Horizons no. 36:70-74.

Kaplan, Robert S. 1999. The Balanced Scorecard for Public-Sector Organizations. In Balanced Scorecard Report. Boston: Harvard Business School Publishing.

Kaplan, Robert S. 2001. "Strategic Performance Measurement and Management in Nonprofit Organizations." Non-Profit Management \& Leadership no. 11 (3).

Kaplan, Steven E., dan Priscilla S. Wisner. 2009. "The Judgmental Effects of Management Communications and a Fifth Balanced Scorecard Category on Performance Evaluation." Behavioral Research In Accounting no. 21 (2):37-56.

Latif, Abdul, Zain Ul Abideen, dan Muhammad Suhail Nazar. 2011. "Individual Political Behavior in Organizational Relationship." Journal of Politics and Law no. 4 (1):199-210.

Lipe, Marlys Gascho, dan Steven E Salterio. 2000. "The Balanced Scorecard: Judgmental Effects of Common and Unique Performance Masures." The Accounting Review no. 75 (3):283-198.

Nahartyo, Ertambang. 2012. Desain dan Implementasi Riset Eksperimen. Yogyakarta: UPP STIM YKPN.

Northcott, Deryl, dan Tuivaiti Maamora Taulapapa. 2012. "Using the Balanced Scorecard to Manage Performance in Public Sector Organizations." International Journal of Public Sector Management no. 25 (3):169-191.

Norton, Andy, dan Diane Elson. 2002. What's Behind the Budget? Politics, Rights and Accountability in the Budget Process. London: Overseas Development Institute.

Pfeffer, Jeffrey, dan Gerald R. Salancik. 1974. "Organizational Decision Making as a Political Process: The Case of a University Budget." Administrative Science Quarterly no. 19 (2):135-151. 
Reck, Jacqueline L. 2000. "Ethics and Budget Allocation Decisions of Municipal Budget Officers." Journal of Business Ethics no. 27 (4):335-350.

Sharma, Bishnu, dan David Gadenne. 2011. "Balanced Scorecard Implementation in a Local Government Authority: Issues and Challenges." The Australian Journal of Public Administration no. 2:167-184.

Slovic, Paul, dan Douglas MacPhillamy. 1974. "Dimensional Commensurability and Cue Utilization in Comparative Judgment." Organizational Behavior and Human Performance no. 11 (2):172-194.

Sulistyanti, Umi. 2012. Pengaruh Aspek Kognitif dan Afektif dalam Pengambilan Keputusan dengan Menggunakan Balanced Scorecard (Studi Eksperimen pada Organisasi Sektor Publik). Tesis (Tidak Diterbitkan), Program Magister Akuntansi, Universitas Gadjah Mada, Yogyakarta.

Surtees, Jennifer, Karin Sanders, Helen Shipton, dan Louise Knight. 2014. "HRM in the NotFor-Profit Sector." In Human Resource Management: Strategic and International Perspectives, edited by Jonathan Crawshaw, Pawan Budhwar and Ann Davis. Thousand Oaks, California: SAGE Publication Inc.

Winarna, Jaka, dan Sri Murni. 2007. Pengaruh Personal Background, Political Background dan Pengetahuan Dew an tentang Anggaran terhadap Peran DPRD dalam Pengaw asan Keuangan Daerah (Studi Kasus Di Karesidenan Surakarta dan Daerah Istimewa Yogyakarta Tahun 2006). In Simposium Nasional Akuntansi X. Makassar. 